\title{
ALDH1 Expression and Vasculogenic Mimicry Are Positively Associated with Poor Prognosis in Patients with Breast Cancer
}

\author{
Peng Xing Huiting Dong Qun Liu Tingting Zhao Fan Yao Yingying Xu \\ Bo Chen Xinyu Zheng Yunfei Wu Feng Jin Jiguang Li
}

Breast Division, The First Hospital of China Medical University, Shenyang, China

Key Words

Aldehyde dehydrogenase $1 \cdot$ Vasculogenic mimicry $•$ Breast cancer $•$ Prognostic value

\begin{abstract}
Background/Aims: This study aimed to explore the prognostic value of aldehyde dehydrogenase 1 (ALDH1) expression and vasculogenic mimicry (VM) in patients with breast cancer. Methods: ALDH1 expression and the presence of VM were examined by immunohistochemistry and CD31/PAS double staining, respectively, using formalin-fixed paraffin-embedded tissues from 202 breast cancer patients. The mean follow-up period ranged from 15 to 115 months. The Kaplan-Meier method was used to plot survival curves. Prognostic values were assessed by multivariate analysis using the Cox regression model. Results: ALDH1 expression was strongly associated with VM $(P=0.005)$. ALDH1 expression was positively correlated with histological grade $(P=0.011)$. Both ALDH1 expression and VM were negatively related to the status of the estrogen receptor and progesterone receptor and were statistically increased in triplenegative breast cancer. Patients with ALDH1 expression or VM displayed poorer disease-free survival (DFS) and overall survival (OS) than ALDH1-negative or VM-negative patients, with the worst OS and DFS observed in ALDH1/VM-double-positive patients. ALDH1-positive and VM-positive were independent survival risk factors for DFS and OS. Conclusion: ALDH1 expression and VM are correlated with the survival rate of patients with breast cancer. ALDH1 and $\mathrm{VM}$, either alone or together, are prognostic factors in patients with breast cancer.
\end{abstract}

(C) 2018 The Author(s)

Published by S. Karger AG, Basel

\section{Introduction}

Breast cancer is the most prevalent malignant neoplasm diagnosed among women worldwide $[1,2]$ It is the leading cause of death from cancer in low- and middle-income developing countries, and is the second leading cause of death among women in developed countries [3]. Despite our improved understanding of the pathophysiology of breast cancer and the use of surgery as a 
treatment option, local recurrence and distant metastasis still remain complex challenges. Many pathological factors, such as histological staging grade, tumor type, and some hormone receptors (e.g., estrogen receptor [ER], progesterone receptor [PR], and human epithelial growth factor receptor-2 [HER2]), play important roles in the clinical diagnosis and treatment of breast cancer [4]. Nevertheless, the prognostic values of the above factors are limited. Hence, it is of great significance to identify reliable molecular prognostic markers for the diagnosis and treatment of breast cancer.

Aldehyde dehydrogenase 1 (ALDH1) is a detoxifying enzyme that is responsible for the oxidation and metabolism of intracellular aldehydes [5]. ALDH1 is involved in the oxidation of retinol to retinoic acid during early stem cell differentiation [6]. In addition, ALDH1 is regarded as a marker of cancer stem cells (CSCs) and progenitor cells [7, 8]. ALDH1 is expressed in a variety of malignant tumors, including human breast cancer [9]. Previous studies confirmed that high levels of ALDH1 activity are predictive of poor prognosis in breast cancer [10]. Moreover, it has been reported that aspirin decreases the stem cell properties of ALDH1-positive colorectal cancer [11].

It is well acknowledged that the growth and distant dissemination of tumors require an adequate blood supply. Therefore, increasing attention has been paid to the functional role of angiogenesis in these processes. However, the limited efficacy and short-term effect of antiangiogenic drugs have led to the investigation of other underlying potential mechanisms. Recently, vasculogenic mimicry (VM) has been proposed as an important factor for angiogenesis. VM refers to a unique process in which aggressive tumor cells mimic the pattern of embryonic vasculogenic networks by forming microvascular channels [12]. VM has been found in many malignant tumors [13], including hepatocellular carcinoma [14], glioblastoma [15], small-cell lung cancer [16], and breast cancer [17]. A recent study showed that CSCs are responsible for the induction of VM, and VM can be mediated by a CSC subpopulation in patients with triple-negative (ER/PR/HER2negative) breast cancer [18]. Furthermore, VM has been shown to play a critical role in tumor progression and metastasis, which is responsible for the poor prognosis of patients with cancer [19].

Although ALDH1 is expressed in CSCs that are involved in VM, little is known about the correlation between ALDH1 expression and VM in patients with breast cancer and their correlations with other clinical parameters. In this study, we analyzed the expression of ALDH1, presence of $\mathrm{VM}$, and their combination in breast tumors to determine their significance in relation to clinicopathologic characteristics and prognosis in patients with breast cancer.

\section{Materials and Methods}

\section{Patient samples}

Formalin-fixed paraffin-embedded (FFPE) tissues from 202 patients with breast cancer in the Breast Division of the First Hospital of China Medical University were used in this study. Informed consent was obtained from all patients, and the institutional ethics committee of the First Hospital of China Medical University approved the study. The diagnosis and classification of breast cancer were according to the tumor-node-metastasis (TNM) system of the American Joint Committee on Cancer [20]. Demographic and pathological profiles including age at diagnosis, histological grade, T stage, $\mathrm{N}$ stage, ER/PR/HER2 status, subtype, and treatments were recorded.

\section{Immunohistochemistry for ALDH1}

ALDH1 expression was assessed using a mouse monoclonal anti-ALDH1 antibody (clone 44, 1:200 dilution; BD Biosciences, San Jose, CA) by immunohistochemistry (IHC). Briefly, tissue samples ( $5 \mu \mathrm{m}$ ) were fixed in $4 \%$ formaldehyde and embedded in paraffin. The sections were then treated with Target Retrieval $(0.01 \mathrm{~mol} / \mathrm{L} ; \mathrm{pH} 6.0)$ under high pressure using a microwave for $15 \mathrm{~min}$. Endogenous peroxidase activity was blocked by Dako Dual Endogenous Enzyme Block (Dako, Carpinteria, CA) for $10 \mathrm{~min}$. The sections were subsequently incubated with an anti-ALDH1A1 antibody for $30 \mathrm{~min}$ at room temperature, followed with a horseradish peroxidase-labeled rabbit anti-mouse secondary antibody. The sections were washed with phosphate-buffered saline (PBS) and incubated with Envision+ Rabbit Polymer (cat. no. K4003; Dako) for $30 \mathrm{~min}$. The staining was then visualized using $200 \mu \mathrm{L}$ DAB plus (Dako) chromogen for $10 \mathrm{~min}$ and counterstained with Mayer's hematoxylin-eosin (magnification $\times 400$ ). Negative controls were performed by substituting the primary antibody with either PBS or isotype-specific IgG controls. 


\section{Cellular Physiology and Biochemistry \\ Cell Physiol Biochem 2018;49:961-970 \\ \begin{tabular}{l|l}
\hline DOI: 10.1159/000493227 & (C) 2018 The Author(s). Published by S. Karger AG, Basel
\end{tabular} \\ Published online: 5 September, 2018 www.karger.com/cpb}

Xing et al.: Prognostic Value of ALDH1 and VM in Breast Cancer

\section{Evaluation of IHC staining}

Semi-quantitative evaluation of the slides was performed by three independent experienced blinded raters. Discrepancies were resolved through consensus. The expression pattern of ALDH1 was assessed by comparing the intensity and distribution of immunoreactivity in positive and negative controls. Generally, percentage labeling indices were determined by evaluating five randomly selected fields $(>1,000$ cells) (magnification $\times 400$ ). The positive-stained cells were graded as: $0,<5 \%$ positive cells; $1,5-25 \%$ positive cells; $2,26-50 \%$ positive cells; and $3,>50 \%$ positive cells.

\section{Periodic acid-Schiff-CD31 dual staining for VM}

It has been established that CD31 is a marker for endothelial cells, while CD31-negative and periodic acid-Schiff (PAS)-positive cells indicate VM [21]. Therefore, we performed CD31-PAS dual-staining to confirm the presence of VM. First, IHC staining with an anti-CD31 primary antibody (Cat. \#TA500124; Beijing Zhongshan Biotechnology Co., Ltd., Beijing, China; dilution 1:40) was performed, following by a secondary rabbit anti-goat antibody (Zhongshan Golden Bridge Biotechnology Co., Ltd., Beijing, China). Thereafter, the sections were exposed to $1 \%$ sodium periodate for $10 \mathrm{~min}$, rinsed with distilled water for 5 $\mathrm{min}$, and then incubated with $0.5 \%$ periodic acid solution for $10 \mathrm{~min}$. The sections were then treated with Schiff's reagent for $15 \mathrm{~min}$ in the dark and washed with distilled water for $5 \mathrm{~min}$. Subsequently, the sections were counterstained with hematoxylin, dehydrated in graded ethanol solutions, cleared with xylene, and mounted with mounting medium (Richard-Allan Scientific, Kalamazoo, MI) for microscopic examination.

\section{Statistical analysis}

The correlations between the clinicopathologic parameters and ALDH1 expression or VM were examined using a two-tailed chi-square test. Survival curves were generated by the Kaplan-Meier method, and differences in survival time were compared by the log rank test. Prognostic independent factors were established by univariate or multivariate analysis using Cox proportional-hazard regression models. Diseasefree survival (DFS) and overall survival (OS) were calculated. All statistical analyses were conducted with SPSS version 18 (SPSS, Inc., Chicago, IL). $P<0.05$ was considered to indicate a significant difference.

\section{Results}

\section{Demographic and pathological profiles of patients with breast cancer}

The demographic and pathological profiles of the patients with breast cancer included in this study are listed in Table 1. We considered factors that correlated with the diagnosis, prognosis, and treatment of breast cancer, including age at the time of diagnosis, histological grade, T stage, N stage, ER status, subtype of cancer, operative approach, and adjuvant therapy. ER/PR-positive was defined as a positive percentage $\geq 1 \%$, and ER/PR-negative was defined as a positive percentage <1\% [22]. HER2-positive was defined as IHC3+, IHC2+ reflected fluorescent in situ hybridization and was categorized as HER2+ for a ratio of $>2.2$ using a dual color system, while HER2-negative was defined as IHCO or 1+ [23]. At the end of the follow-up period, 156 patients $(77.22 \%)$ were alive, while 46 patients $(22.78 \%)$ died because of local recurrence and metastasis (40), heart disease (4), and other malignancy (2).

\section{ALDH1 expression in invasive breast cancer}

ALDH1 expression was detected by IHC. Examples of ALDH1-negative and ALDH1-positive samples are shown in Fig. 1A and 1B-E, respectively. ALDH1 expression and its relationship with clinicopathological parameters are listed in Table 2. From the table, we observed that ALDH1 expression was significantly higher in patients $<50$ years old than in patients $\geq 50$ years old $(P=0.004)$. In addition, ALDH1 expression was positively correlated with histological grade $(P$ $=0.011)$ and it was negatively related with $\operatorname{ER}(P=0.000)$ and $\operatorname{PR}(P=0.000)$. Compared with the non-triple-negative patients, ALDH1 expression was significantly increased in triple-negative patients $(P=0.002)$. Moreover, ALDH1 expression was strongly associated with VM $(P=0.005)$; however, no significant differences were found between ALDH1 expression and T status $(P=$ $0.628), \mathrm{N}$ status $(P=0.759)$, or HER2 status $(P=1.000)$. These results indicated that ALDH1 expression was associated with invasive breast cancer.

VM in invasive breast cancer

PAS/CD31 double staining was used to confirm the presence of VM. As shown in Fig. 2, CD31negative (Fig. 2A) and PAS-positive loops (Fig. 2B) could be found rounding tumor cells, indicating the presence of VM in breast cancer. The relationships between VM and clinicopathological 
Fig. 1. ALDH1 expression in FFPE tissues from patients with breast cancer. ALDH1 expression was detected by IHC using a mouse monoclonal anti-ALDH1 antibody. Original magnification: $\times 400$.

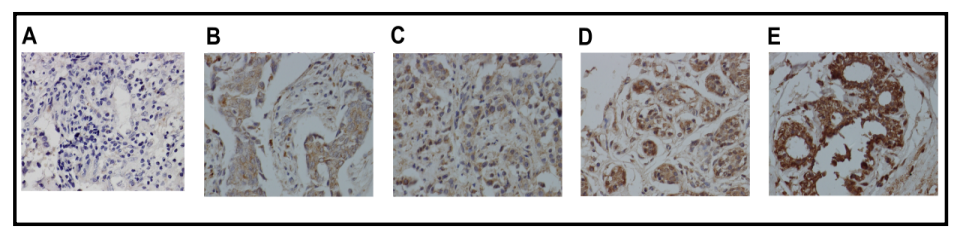
1A, ALDH1-negative expression in corresponding tissues; 1B, ALDH1-positive expression (grade 0) in corresponding tissues; 1C, ALDH1positive expression (grade 1) in corresponding tissues; 1D, ALDH1-positive expression (grade 2) in corresponding tissues; 1E, ALDH1-positive expression (grade 3) in corresponding tissues.

Table 1. Demographic and pathological profiles of patients with breast cancer

\begin{tabular}{|c|c|}
\hline Parameters & N (\%) \\
\hline \multicolumn{2}{|l|}{ Age at diagnosis (years) } \\
\hline$\leq 50$ & $95(47.0)$ \\
\hline$>50$ & $107(53.0)$ \\
\hline \multicolumn{2}{|l|}{ Histological grade } \\
\hline Grade 1 & $31(15.3)$ \\
\hline Grade 2 & $150(74.3)$ \\
\hline Grade 3 & $21(10.4)$ \\
\hline \multicolumn{2}{|l|}{ T stage } \\
\hline $\mathrm{T} 1$ & $61(30.2)$ \\
\hline $\mathrm{T} 2$ & $129(63.9)$ \\
\hline $\mathrm{T} 3$ & $12(5.9)$ \\
\hline \multicolumn{2}{|l|}{$\mathrm{N}$ stage } \\
\hline No & 119 (58.9) \\
\hline N1 & $50(24.8)$ \\
\hline $\mathrm{N} 2$ & $23(11.4)$ \\
\hline N3 & $10(4.9)$ \\
\hline \multicolumn{2}{|l|}{ ER status } \\
\hline Positive & $124(61.4)$ \\
\hline Negative & $78(38.6)$ \\
\hline \multicolumn{2}{|l|}{ PR status } \\
\hline Positive & $108(53.5)$ \\
\hline Negative & $94(46.5)$ \\
\hline \multicolumn{2}{|l|}{ HER2 status } \\
\hline Positive & $29(14.4)$ \\
\hline Negative & $173(85.6)$ \\
\hline \multicolumn{2}{|l|}{ Subtypes } \\
\hline Triple-negative & $72(35.6)$ \\
\hline Non-triple-negative & $130(64.4)$ \\
\hline \multicolumn{2}{|l|}{ Operative approaches } \\
\hline Mastectomy & $190(94.1)$ \\
\hline Breast-conserving surgery & $12(5.9)$ \\
\hline \multicolumn{2}{|l|}{ Adjuvant therapy } \\
\hline Both chemotherapy and endocrine therapy & $68(33.7)$ \\
\hline Only chemotherapy & $101(50.0)$ \\
\hline Only endocrine therapy & $4(1.9)$ \\
\hline None & $29(14.4)$ \\
\hline
\end{tabular}

Table 2. Relationship of ALDH1 and clinicopathological parameters in invasive breast cancer

\begin{tabular}{|c|c|c|c|}
\hline \multirow{2}{*}{ Parameters } & \multicolumn{2}{|c|}{ ALDH1 status } & \multirow{2}{*}{$P$} \\
\hline & Negative (\%) & Positive (\%) & \\
\hline Age & & & 0.004 \\
\hline$\leq 50$ & $55(57.9)$ & $40(42.1)$ & \\
\hline$>50$ & $83(77.6)$ & $24(22.4)$ & \\
\hline Grade & & & 0.011 \\
\hline I & $28(90.3)$ & $3(9.7)$ & \\
\hline II & $96(64.0)$ & $54(36.0)$ & \\
\hline III & 14(66.7) & $7(33.3)$ & \\
\hline T status & & & 0.628 \\
\hline $\mathrm{T} 1$ & $33(63.9)$ & $22(36.1)$ & \\
\hline T2 & $91(70.5)$ & $38(29.5)$ & \\
\hline T3 & $8(66.7)$ & $4(33.3)$ & \\
\hline $\mathrm{N}$ status & & & 0.759 \\
\hline No & $83(69.7)$ & $36(30.3)$ & \\
\hline N1 & $35(70.0)$ & $15(30.0)$ & \\
\hline $\mathrm{N} 2$ & $15(65.2)$ & $8(34.8)$ & \\
\hline N3 & $5(50.0)$ & $5(50.0)$ & \\
\hline ER status & & & 0.000 \\
\hline Negative & $41(52.6)$ & $37(47.4)$ & \\
\hline Positive & $97(78.2)$ & $27(21.8)$ & \\
\hline PR status & & & 0.000 \\
\hline Negative & $52(55.3)$ & $42(44.7)$ & \\
\hline Positive & $86(79.6)$ & $24(20.4)$ & \\
\hline HER2 status & & & 1.000 \\
\hline Negative & $118(68.2)$ & $55(31.8)$ & \\
\hline Positive & $20(69.0)$ & $9(31.0)$ & \\
\hline Subtypes & & & 0.002 \\
\hline Triple-negative & $39(54.2)$ & $33(45.8)$ & \\
\hline Non-triple-negative & $99(76.2)$ & $31(23.8)$ & \\
\hline VM & & & 0.005 \\
\hline Positive & $122(72.6)$ & $46(27.4)$ & \\
\hline Negative & $16(47.1)$ & 18(52.9) & \\
\hline
\end{tabular}


Fig. 2. VM in in FFPE tissues from patients with breast cancer. VM was confirmed by CD31/PAS double staining. Original magnification: $\times 200$. 2A, CD31-negative and PAS-negative staining; 2B, VM identified by CD31/PAS double staining.

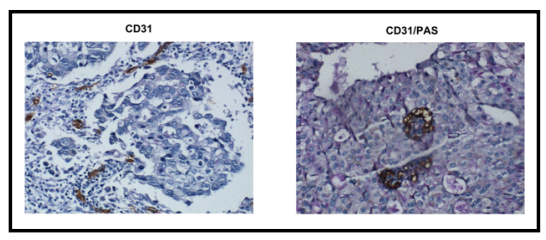

Table 3. Relationship of VM and clinicopathological parameters in invasive breast cancer

\begin{tabular}{|c|c|c|c|}
\hline \multirow{2}{*}{ Parameters } & \multicolumn{2}{|c|}{$\mathrm{PAS}+/ \mathrm{CD} 31-$} & \multirow{2}{*}{$P$} \\
\hline & Negative (\%) & Positive (\%) & \\
\hline Age & & & 0.257 \\
\hline$\leq 50$ & $76(80.0)$ & $19(20.0)$ & \\
\hline$>50$ & $92(86.0)$ & $15(14.0)$ & \\
\hline Grade & & & 0.190 \\
\hline I & $28(90.3)$ & $3(9.7)$ & \\
\hline II & $125(83.3)$ & $25(16.7)$ & \\
\hline III & $15(71.4)$ & $6(28.6)$ & \\
\hline T status & & & 1.000 \\
\hline $\mathrm{T} 1$ & $51(83.6)$ & $10(16.4)$ & \\
\hline $\mathrm{T} 2$ & $107(82.9)$ & $22(17.1)$ & \\
\hline $\mathrm{T} 3$ & $10(83.3)$ & $2(16.7)$ & \\
\hline $\mathrm{N}$ status & & & 0.058 \\
\hline No & $96(80.7)$ & 23(19.3) & \\
\hline $\mathrm{N} 1$ & $46(92.0)$ & $4(8.0)$ & \\
\hline $\mathrm{N} 2$ & $20(86.7)$ & $3(13.3)$ & \\
\hline N3 & $6(60.0)$ & $4(40.0)$ & \\
\hline ER status & & & 0.000 \\
\hline Negative & $55(70.5)$ & $23(29.5)$ & \\
\hline Positive & 113(91.1) & $11(8.9)$ & \\
\hline PR status & & & 0.002 \\
\hline Negative & $70(74.5)$ & $24(25.5)$ & \\
\hline Positive & $98(90.7)$ & $10(9.3)$ & \\
\hline HER2 status & & & 0.179 \\
\hline Negative & $141(81.5)$ & $32(18.5)$ & \\
\hline Positive & $27(93.1)$ & $2(6.9)$ & \\
\hline Subtypes & & & 0.003 \\
\hline Triple-negative & $52(72.2)$ & $20(27.8)$ & \\
\hline Non-triple-negative & $116(89.2)$ & $14(10.8)$ & \\
\hline
\end{tabular}

Table 4. Relationship of ALDH1 and VM simultaneous positive and clinicopathological parameters in invasive breast cancer

\begin{tabular}{|c|c|c|c|}
\hline \multirow{2}{*}{ Parameters } & \multicolumn{2}{|c|}{ Both ALDH1 and VM expression } & \multirow{2}{*}{$P$} \\
\hline & Negative (\%) & Positive (\%) & \\
\hline Age & & & 0.810 \\
\hline$\leq 50$ & $86(90.5)$ & $9(9.5)$ & \\
\hline$>50$ & $98(91.6)$ & $9(8.4)$ & \\
\hline Grade & & & 0.076 \\
\hline I & $32(100.0)$ & $0(0.0)$ & \\
\hline II & $135(90.0)$ & $15(10.0)$ & \\
\hline III & 18(85.7) & $3(14.3)$ & \\
\hline T status & & & 1.000 \\
\hline $\mathrm{T} 1$ & $56(91.8)$ & $5(8.2)$ & \\
\hline $\mathrm{T} 2$ & $117(90.7)$ & $12(9.3)$ & \\
\hline $\mathrm{T} 3$ & $11(91.7)$ & $1(8.3)$ & \\
\hline $\mathrm{N}$ status & & & 0.359 \\
\hline No & $110(92.4)$ & $9(7.6)$ & \\
\hline N1 & $46(92.0)$ & $4(8.0)$ & \\
\hline N2 & $20(87.0)$ & $3(13.0)$ & \\
\hline N3 & $8(80.0)$ & $2(20.0)$ & \\
\hline ER status & & & 0.000 \\
\hline Negative & $63(80.8)$ & $15(19.2)$ & \\
\hline Positive & $121(97.6)$ & $3(2.4)$ & \\
\hline PR status & & & 0.000 \\
\hline Negative & $78(83.0)$ & $16(17.0)$ & \\
\hline Positive & 106(98.1) & $2(1.9)$ & \\
\hline HER2 status & & & 0.480 \\
\hline Negative & $156(90.2)$ & $17(9.8)$ & \\
\hline Positive & $28(96.6)$ & $1(3.4)$ & \\
\hline Subtypes & & & 0.001 \\
\hline Triple-negative & $59(81.9)$ & $13(18.1)$ & \\
\hline Non-triple-negative & $125(96.2)$ & $5(3.8)$ & \\
\hline
\end{tabular}

parameters are listed in Table 3; 34 cases (16.8\%) were VM-positive, while 168 cases (83.2\%) were VM-negative. PAS-positive/CD31-negative was negatively associated with ER status $(P$ $=0.000)$ and PR status $(P=0.002)$. The presence of VM was significantly higher in the triplenegative cases than in the non-triple-negative cases $(P=0.003)$. Nevertheless, there were no significant differences between PAS-positive/CD31-negative and age $(P=0.257)$, histological grade $(P=0.190)$, T status $(P=1.000), \mathrm{N}$ status $(P=0.058)$, and HER2 status $(P=0.179)$. These results demonstrated that $\mathrm{VM}$ was also involved in invasive breast cancer.

\section{ALDH1/VM-double-positive invasive breast cancer}

The relationships between ALDH1-positive and VM-positive status and clinicopathological parameters are summarized in Table 4. As shown in the table, there were 122 ALDH1- and VMnegative cases (60.4\%), 46 ALDH1-positive and VM-negative cases (27.8\%), 16 ALDH1-negative and VM-positive cases (7.9\%), and 18 ALDH1/VM-double-positive cases (8.9\%). Interestingly, ALDH1/VM-double-positive status was negatively correlated with ER status $(P=0.000)$ and 
Fig. 3. Kaplan-Meier plots of DFS in breast cancer patients with different ALDH1 and/or VM statuses. The Kaplan-Meier method was used to plot survival curves, and survival rate was compared with the log-rank test. 3A, Survival
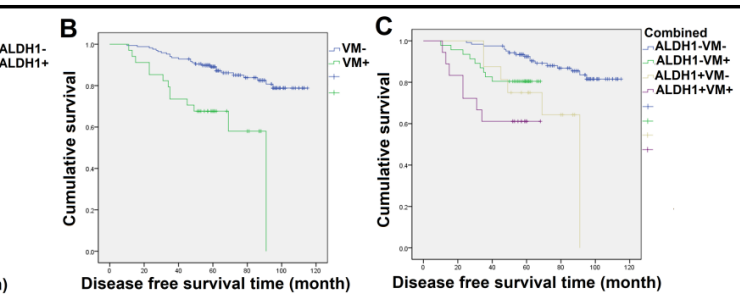

curve of DFS in breast cancer patients with different ALDH1 statuses; 3B, Survival curve of DFS in breast cancer patients with different VM statuses; 3C, Survival curve of DFS in breast cancer patients with different ALDH1 and VM statuses.

Fig. 4. Kaplan-Meier plots of OS in breast cancer patients with different ALDH1 and/or VM statuses. The KaplanMeier method was used to plot survival curves, and survival rate was compared

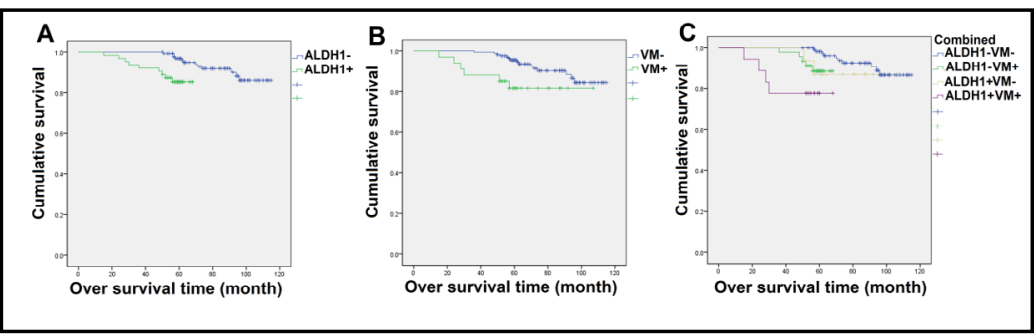
with the log-rank test. $4 \mathrm{~A}$,

Survival curve of OS in breast cancer patients with different ALDH1 statuses; 4B, Survival curve of OS in breast cancer patients with different VM statuses; 4C, Survival curve of OS in breast cancer patients with different ALDH1 and VM statuses.

PR status $(P=0.000)$ and was statistically higher in the triple-negative cases than in the non-triple-negative cases $(P=0.001)$. However, we found no significant differences between ALDH1/VM-double-positive status and age $(P=0.810)$, histological grade $(P=$ $0.076)$, T status $(P=1.000), \mathrm{N}$ status $(P=$ $0.058)$, and HER2 status $(P=0.480)$. These results suggested that there was a strong relationship between ALDH1 expression and VM in invasive breast cancer.

\section{ALDH1 and/or VM status and DFS}

Kaplan-Meier plots of DFS in breast cancer patients with different ALDH1 and/or VM statuses are shown in Fig. 3. Univariate analysis demonstrated that the mean DFS of ALDH1-positive patients (log-rank = 9.662, $P=0.002$ ), VM-positive patients (log-rank = $16.128, P=0.000$ ), and ALDH1/VM-double-positive patients (log-rank $=22.893, P=0.000$ ) was significantly worse than that of ALDH1-negative patients, VM-negative patients, and ALDH1/VMdouble-negative patients, respectively. The mean DFS of ALDH1-positive and ALDH1-negative patients was 58 months and 84 months, respectively (Fig. 3A). The mean DFS of VM-positive and VM-negative patients was 57 months and 64 months, respectively (Fig. 3B). The mean DFS of ALDH1/VM-double-positive and ALDH1/VM-double-negative patients was 52 months and 59 months, respectively (Fig. 3C). These results implied that ALDH1 and VM, either alone or together, are indicators of DFS in patients with breast cancer.

\section{ALDH1 and/or VM status and OS}

Kaplan-Meier plots of OS in breast cancer patients with different ALDH1 and/or VM statuses are shown in Fig. 4. The OS of ALDH1-positive patients (log-rank = 9.765, $P=0.002$ ), VM-positive patients (log-rank $=5.867, P=0.015$ ), and ALDH1/VM-double-positive patients (log-rank $=15.718, P=0.001$ ) was also significantly poorer than that of ALDH1-negative patients, VM- 


\section{Cellular Physiology Cell Physiol Biochem 2018:49:961-970

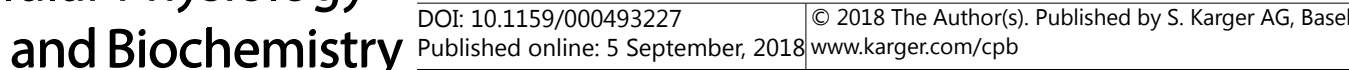

Xing et al.: Prognostic Value of ALDH1 and VM in Breast Cancer

negative patients, and ALDH1/VM-doublenegative patients, respectively. The mean OS of ALDH1-positive and ALDH1-negative patients was 58 months and 88 months, respectively (Fig. 4A). The mean OS of VM-positive and VM-negative patients was 64 months and 70 months, respectively (Fig. 4B). The mean OS of ALDH1/VM-double-positive and ALDH1/ VM-double-negative patients was 55 months and 88 months, respectively (Fig. 4C). These results implied that ALDH1 and VM, either alone or together, are indicators of OS in patients with breast cancer.
Table 6. The survival risk factors of OS

\begin{tabular}{lccccc}
\hline & \multirow{2}{*}{ Beta } & HR & \multicolumn{3}{c}{$95 \%$ CI } \\
& & & Lower & Upper & P \\
\hline Age & 0.947 & 2.577 & 0.941 & 7.056 & 0.066 \\
Grade & 0.188 & 1.206 & 0.484 & 3.005 & 0.687 \\
T status & 0.258 & 1.295 & 0.528 & 3.176 & 0.573 \\
N status & 0.686 & 1.986 & 1.300 & 3.034 & 0.002 \\
Both ALDH1 and VM negative & & & - & - & 0.009 \\
ALDH1 positive & 1.706 & 5.509 & 1.434 & 21.157 & 0.013 \\
VM positive & 1.186 & 3.273 & 0.649 & 16.512 & 0.026 \\
Both ALDH1 and VM positive & 2.349 & 10.479 & 2.535 & 43.325 & 0.001 \\
\hline
\end{tabular}

ALDH1, VM, and N status as survival risk factors

Furthermore, the multivariate Cox proportional hazards regression model was used to assess the survival risk factors of DFS and OS. N status (hazard ratio [HR]: $2.049,95 \%$ confidence interval [CI]: 1.489-2.819, $P=0.000$ ), ALDH1-positive status (HR: 3.475, 95\% CI: 1.398-8.639, $P$ $=0.007$ ), and VM-positive status (HR: 3.658, 95\% CI: 1.343-9.969, $P=0.011$ ) were independent survival risk factors for DFS. However, no significant differences were found in age, T status, and grade (Table 5). Furthermore, N status (HR: 1.986, 95\% CI: 1.300-3.034, P=0.002), ALDH1positive status (HR: 5.509, 95\% CI: 1.434-21.157, $P=0.013$ ), VM-positive status (HR: 3.273, 95\% CI: 0.649-16.512, $P=0.026$ ), and ALDH1/VM-double-positive status (HR: 10.479, 95\% CI: 2.535-43.325, $P=0.011$ ) were independent survival risk factors for OS (Table 6).

\section{Discussion}

In this study, we observed that both ALDH1 expression and VM correlated with the survival rate in patients with breast cancer. ALDH1 expression was positively correlated with histological grade. ALDH1-positive, VM-positive, and ALDH1/VM-double-positive were negatively correlated with ER status and PR status. ALDH1 expression and VM were markedly found in patients with triple-negative breast cancer. Patients with ALDH1 expression or VM had comparatively poorer DFS and OS than ALDH1-negative or VM-negative patients. Further, we confirmed that ALDH1positive and VM-positive were independent survival risk factors for DFS and OS.

Breast cancer is a heterogeneous disease with various histological types, different molecular features, diverse biological behaviors, and responses to therapy [24, 25]. The progression of breast cancer is affected by host- and tumor-related factors, such as age, tumor size, histological grade, lymph node status, ER status, PR status, and HER status [26]. There is an urgent need to determine precise prognostic markers to guide treatment decisions. We focused on ALDH1 expression and the presence of VM. CSCs represent a small percentage of tumor cells and are characterized by the stem cell property of self-renewal [27]. An increasing number of studies have confirmed that CSCs have the ability to initiate cancer and promote metastasis [28, 29]. CSCs have been described and isolated from numerous tumors, including breast cancer [30]. ALDH1 synthesizes retinoic acid in the retina and has been identified as a marker of stem/progenitor cells, which are a key regulator of self-renewal and differentiate into normal stem cells and CSCs [31]. Much attention has been focused on the clinicopathologic features and prognostic value of ALDH1 in breast cancer; however, the reported results are controversial. For example, many studies confirmed that an ALDH1-positive status was negatively associated with ER status and/or PR status, and was positively correlated with HER2 status and TNM stage [32-35]. In addition, an ALDH1-positive status indicates a poor prognosis in patients with breast cancer $[10,33,36-40]$, which is consistent with our findings. Nevertheless, Mieog et al. discovered that the prognostic value of ALDH1 expression is age-dependent and can only be found in patients younger than 65 years of age [41]. Neumeister et al. revealed that there was no significant difference between an ALDH1-positive status and the prognostic value of breast cancer [37]. The differences among the studies may be due to the sample sizes and the length of the follow-up periods.

Recently, anti-angiogenic drugs for oncotherapy have been developed at an increased rate $[42,43]$. Although many patients have obtained benefits from blockers of angiogenic proteins, 


\section{Cellular Physiology Cell Physiol Biochem 2018:49:961-970 \begin{tabular}{l|l|l|l|} 
DO 2018 The Author(s). Published by S. Karger AG, Basel \\
and Biochemistry
\end{tabular}}

Xing et al.: Prognostic Value of ALDH1 and VM in Breast Cancer

such as vascular endothelial growth factor, their limited efficacy and short-term effect still remain prominent problems [43]. VM serves as an angiogenesis-independent mechanism and is a novel developmental program for tumor blood supply, which is frequently activated during cancer metastasis by forming vascular networks $[18,44]$. VM can interact indirectly or directly with other vasculatures via a special passage, but without endothelial cells $[45,46]$. VM has been reported to be responsible for more aggressive tumor biology and increased mortality [18, 44, $45,47]$. Recent studies demonstrate that VM functions as an unfavorable prognostic indicator in various tumors including breast cancer $[48,49]$. In our study, we found that VM was negatively related with ER status and PR status, and VM was also significantly higher in patients with triplenegative breast cancer. In addition, the presence of VM was associated with poorer DFS and OS compared to the absence of VM. Our study was consistent with a previous one suggesting that VM is an unfavorable prognostic indicator in patients with breast cancer [48]. It is noteworthy that our results are the first to identify the strong positive relationship between VM and ALDH1. Therefore, we propose that the combination of ALDH1 expression and the presence of VM might provide a more accurate prognostic judgment for patients with breast cancer. Interestingly, our results demonstrated that ALDH1/VM-double-positive status was negatively associated with ER status and PR status, and was also significantly increased in triple-negative breast cancer samples. Moreover, our results indicated that ALDH1/VM-double positive patients had the worst OS and DFS. Consistent with previous studies, the results of Cox multivariate analysis in our study established that ALDH1-positive status and the presence of VM were both independent prognostic factors for DFS and OS, and the co-existence of ALDH1-positive expression and VM was also an independent prognostic factor for DFS and OS in patients with breast cancer.

In conclusion, our results suggest that ALDH1 and VM, either alone or together, are prognostic factors in patients with breast cancer. Both ALDH1 and VM are correlated with survival rates in patients with breast cancer.

\section{Disclosure Statement}

This study received no specific grant from any funding agency in the public, commercial, or not-for-profit sectors. The authors declare to have no conflicts of interest.

\section{References}

1 Li T, Mellothoms C, Brennan PC: Descriptive epidemiology of breast cancer in China: incidence, mortality, survival and prevalence. Breast Cancer Res Treat 2016;159:395-406.

-2 Jemal A, Bray F, Center MM, Ferlay J, Ward E, Forman D: Global cancer statistics. Ca A Cancer Jr Clinic 2011;61:69-90.

- Lauby-Secretan B, Scoccianti C, Loomis D, Benbrahim-Tallaa L, Bouvard V, Bianchini F, Straif K: Breastcancer screening--viewpoint of the IARC Working Group. New En J Med 2015;373:2353-2358.

4 Liu T, Sun B, Zhao X, Li Y, Gu Q, Dong X, Liu F: OCT4 expression and vasculogenic mimicry formation positively correlate with poor prognosis in human breast cancer. Int J Mol Sci 2014;15:19634-19649.

5 Duester G: Families of retinoid dehydrogenases regulating vitamin A function: production of visual pigment and retinoic acid. Eur J Biochem 2000;267:4315-4324.

6 Yoshida A: Molecular genetics of human aldehyde dehydrogenase. Pharmacogenetics 1992;2:139-147.

7 Douville J, Beaulieu R, Balicki D: ALDH1 as a functional marker of cancer stem and progenitor cells. Stem Cells Dev 2009;18:17-25.

8 Ma I, Allan AL: The role of human aldehyde dehydrogenase in normal and cancer stem cells. Stem Cell Rev 2011;7:292-306.

-9 Lee HE, Kim JH, Kim YJ, Choi SY, Kim SW, Kang E, Chung IY, Kim IA, Kim EJ, Choi Y, Ryu HS, Park SY: An increase in cancer stem cell population after primary systemic therapy is a poor prognostic factor in breast cancer. Br J Cancer 2011;104:1730-1738.

10 Ohi Y, Umekita Y, Yoshioka T, Souda M, Rai Y, Sagara Y, Sagara Y, Sagara Y, Tanimoto A: Aldehyde dehydrogenase 1 expression predicts poor prognosis in triple-negative breast cancer. Histopathology 2011;59:776-780. 


\section{Cellular Physiology Cell Physiol Biochem 2018;49:961-970 \begin{tabular}{l|l|l|l|l} 
CO 2018 The Author(s). Published by S. Karger AG, Basel \\
and Biochemistry
\end{tabular}}

Xing et al.: Prognostic Value of ALDH1 and VM in Breast Cancer

11 Wang H, Liu B, Wang J, Li J, Gong Y, Li S, Wang C, Cui B, Xue X, Yang M, Fan W, Kang Z, Kamran M, Xu J, Tian P, Luo Y, Hou Z, Dong L, Ren Y, Li M, Wen Q, Cheng W, Xu L, Wang L, Liu Q: Reduction of NANOG Mediates the Inhibitory Effect of Aspirin on Tumor Growth and Stemness in Colorectal Cancer. Cell Physiol Biochem 2017;44:1051-1063.

12 Qiao L, Liang N, Zhang J, Xie J, Liu F, Xu D, Yu X, Yuan T: Advanced research on vasculogenic mimicry in cancer. J Cell Mol Med 2015;19:315-326.

-13 Dw VDS, Seftor RE, Seftor EA, Hess AR, Gruman LM, Kirschmann DA, Yokoyama Y, Griffioen AW, Hendrix MJ: Effects of angiogenesis inhibitors on vascular network formation by human endothelial and melanoma cells. Cancerspect Knowl Environm 2004;96:1473-1477.

14 Sun B, Zhang S, Zhang D, Du J, Guo H, Zhao X, Zhang W, Hao X: Vasculogenic mimicry is associated with high tumor grade, invasion and metastasis, and short survival in patients with hepatocellular carcinoma. Oncology Rep 2006;16:693-698.

15 El HS, Boisselier B, Peglion F, Rousseau A, Colin C, Idbaih A, Marie Y, Mokhtari K, Thomas JL, Eichmann A: A new alternative mechanism in glioblastoma vascularization: tubular vasculogenic mimicry. Brain 2010;133:973-982.

16 Trapani F, Williamson S, Metcalf RL, Hui SL, Abbott B, Antonello J, Hodgkinson C, Franklin L, Hendrix MJ, Seftor REB: Abstract 3371: Genetic, phenotypic and functional characterisation of vasculogenic mimicry in small-cell lung cancer. 2016;76:3371-3371.

17 Wagenblast E, Soto M, Gutiérrez-Ángel S, Hartl CA, Gable AL, Maceli AR, Erard N, Williams AM, Kim SY, Dickopf S: A model of breast cancer heterogeneity reveals vascular mimicry as a driver of metastasis. Nature 2015;520:358-362.

18 Liu TJ, Sun BC, Zhao XL, Zhao XM, Sun T, Gu Q, Yao Z, Dong XY, Zhao N, Liu N: CD133+ cells with cancer stem cell characteristics associates with vasculogenic mimicry in triple-negative breast cancer. Oncogene 2013;32:544-553.

19 Cao Z, Bao M, Miele L, Sarkar FH, Wang Z, Zhou Q: Tumour vasculogenic mimicry is associated with poor prognosis of human cancer patients: A systemic review and meta-analysis. 2013;49:3914-3923.

20 Singletary SE, Allred C, Ashley P, Bassett LW, Berry D, Bland KI, Borgen PI, Clark GM, Edge SB, Hayes DF, Hughes LL, Hutter RV, Morrow M, Page DL, Recht A, Theriault RL, Thor A, Weaver DL, Wieand HS, Greene FL: Staging system for breast cancer: revisions for the 6th edition of the AJCC Cancer Staging Manual. Surg Clin North Am 2003;83:803-819.

21 Zhang L, Xu Y, Sun J, Chen W, Zhao L, Ma C, Wang Q Sun J, Huang B, Zhang Y, Li X, Qu X: M2-like tumorassociated macrophages drive vasculogenic mimicry through amplification of IL-6 expression in glioma cells. Oncotarget 2017;8:819-832.

-22 Allred DC, Carlson RW, Berry DA, Burstein HJ, Edge SB, Goldstein LJ, Gown A, Hammond ME, Iglehart JD, Moench S, Pierce LJ, Ravdin P, Schnitt SJ, Wolff AC: NCCN Task Force Report: Estrogen Receptor and Progesterone Receptor Testing in Breast Cancer by Immunohistochemistry. J Natl Compr Canc Netw 2009;7:S1-S21; quiz S22-23.

-23 Allred DC, Harvey JM, Berardo M, Clark GM: Prognostic and predictive factors in breast cancer by immunohistochemical analysis. Mod Pathol 1998;11:155-168.

24 Cancer Genome Atlas N: Comprehensive molecular portraits of human breast tumours. Nature 2012;490:61-70.

25 Perou CM, Sorlie T, Eisen MB, van de Rijn M, Jeffrey SS, Rees CA, Pollack JR, Ross DT, Johnsen H, Akslen LA, Fluge 0, Pergamenschikov A, Williams C, Zhu SX, Lonning PE, Borresen-Dale AL, Brown PO, Botstein D: Molecular portraits of human breast tumours. Nature 2000;406:747-752.

26 Lal P, Tan LK, Chen B: Correlation of HER-2 status with estrogen and progesterone receptors and histologic features in 3, 655 invasive breast carcinomas. Am J Clin Pathol 2005;123:541-546.

27 Al-Hajj M, Becker MW, Wicha M, Weissman I, Clarke MF: Therapeutic implications of cancer stem cells. Curr Opin Genet Dev 2004;14:43-47.

28 Gupta PB, Chaffer CL, Weinberg RA: Cancer stem cells: mirage or reality? Nat Med 2009;15:1010-1012.

-29 Zhao D, Najbauer J, Annala AJ, Garcia E, Metz MZ, Gutova M, Polewski MD, Gilchrist M, Glackin CA, Kim SU, Aboody KS: Human neural stem cell tropism to metastatic breast cancer. Stem Cells 2012;30:314-325.

-30 Harrison H, Rogerson L, Gregson HJ, Brennan KR, Clarke RB, Landberg G: Contrasting hypoxic effects on breast cancer stem cell hierarchy is dependent on ER-alpha status. Cancer Res 2013;73:1420-1433.

-31 Koppaka V, Thompson DC, Chen Y, Ellermann M, Nicolaou KC, Juvonen RO, Petersen D, Deitrich RA, Hurley TD, Vasiliou V: Aldehyde dehydrogenase inhibitors: a comprehensive review of the pharmacology, mechanism of action, substrate specificity, and clinical application. Pharmacol Rev 2012;64:520-539.

-32 Morimoto K, Kim SJ, Tanei T, Shimazu K, Tanji Y, Taguchi T, Tamaki Y, Terada N, Noguchi S: Stem cell marker aldehyde dehydrogenase 1-positive breast cancers are characterized by negative estrogen receptor, positive human epidermal growth factor receptor type 2, and high Ki67 expression. Cancer Sci 2009;100:1062-1068. 


\section{Cellular Physiology Cell Physiol Biochem 2018;49:961-970

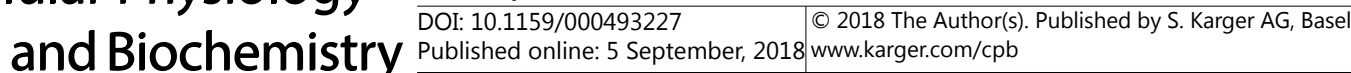

Xing et al.: Prognostic Value of ALDH1 and VM in Breast Cancer

-33 Liu Y, Lv DL, Duan JJ, Xu SL, Zhang JF, Yang XJ, Zhang X, Cui YH, Bian XW, Yu SC: ALDH1A1 expression correlates with clinicopathologic features and poor prognosis of breast cancer patients: a systematic review and meta-analysis. BMC Cancer 2014;14:444.

34 Ricardo S, Vieira AF, Gerhard R, Leitao D, Pinto R, Cameselle-Teijeiro JF, Milanezi F, Schmitt F, Paredes J: Breast cancer stem cell markers CD44, CD24 and ALDH1: expression distribution within intrinsic molecular subtype. J Clin Pathol 2011;64:937-946.

-35 Pan H, Wu N, Huang Y, Li Q, Liu C, Liang M, Zhou W, Liu X, Wang S: Aldehyde dehydrogenase 1 expression correlates with the invasion of breast cancer. Diagn Pathol 2015;10:66.

-36 Ginestier C, Hur MH, Charafe-Jauffret E, Monville F, Dutcher J, Brown M, Jacquemier J, Viens P, Kleer CG, Liu S, Schott A, Hayes D, Birnbaum D, Wicha MS, Dontu G: ALDH1 is a marker of normal and malignant human mammary stem cells and a predictor of poor clinical outcome. Cell Stem Cell 2007;1:555-567.

-37 Neumeister V, Agarwal S, Bordeaux J, Camp RL, Rimm DL: In situ identification of putative cancer stem cells by multiplexing ALDH1, CD44, and cytokeratin identifies breast cancer patients with poor prognosis. Am J Pathol 2010;176:2131-2138.

-38 Yoshioka T, Umekita Y, Ohi Y, Souda M, Sagara Y, Sagara Y, Sagara Y, Rai Y, Tanimoto A: Aldehyde dehydrogenase 1 expression is a predictor of poor prognosis in node-positive breast cancers: a long-term follow-up study. Histopathology 2011;58:608-616.

-39 Sakakibara M, Fujimori T, Miyoshi T, Nagashima T, Fujimoto H, Suzuki HT, Ohki Y, Fushimi K, Yokomizo J, Nakatani Y, Miyazaki M: Aldehyde dehydrogenase 1-positive cells in axillary lymph node metastases after chemotherapy as a prognostic factor in patients with lymph node-positive breast cancer. Cancer 2012;118:3899-3910.

40 Zhong Y, Shen S, Zhou Y, Mao F, Guan J, Lin Y, Xu Y, Sun Q: ALDH1 is a better clinical indicator for relapse of invasive ductal breast cancer than the CD44+/CD24- phenotype. Med Oncol 2014;31:864.

41 Mieog JS, de Kruijf EM, Bastiaannet E, Kuppen PJ, Sajet A, de Craen AJ, Smit VT, van de Velde CJ, Liefers GJ: Age determines the prognostic role of the cancer stem cell marker aldehyde dehydrogenase-1 in breast cancer. BMC Cancer 2012;12:42.

42 Carmeliet P, Jain RK: Molecular mechanisms and clinical applications of angiogenesis. Nature 2011;473:298-307.

43 Potente M, Gerhardt H, Carmeliet P: Basic and therapeutic aspects of angiogenesis. Cell 2011;146:873-887.

-44 Liu T, Sun B, Zhao X, Gu Q, Dong X, Yao Z, Zhao N, Chi J, Liu N, Sun R, Ma Y: HER2/neu expression correlates with vasculogenic mimicry in invasive breast carcinoma. J Cell Mol Med 2013;17:116-122.

45 Seftor RE, Hess AR, Seftor EA, Kirschmann DA, Hardy KM, Margaryan NV, Hendrix MJ: Tumor cell vasculogenic mimicry: from controversy to therapeutic promise. Am J Pathol 2012;181:1115-1125.

-46 Kirschmann DA, Seftor EA, Hardy KM, Seftor RE, Hendrix MJ: Molecular pathways: vasculogenic mimicry in tumor cells: diagnostic and therapeutic implications. Clin Cancer Res 2012;18:2726-2732.

47 Sun T, Sun BC, Zhao XL, Zhao N, Dong XY, Che N, Yao Z, Ma YM, Gu Q Zong WK, Liu ZY: Promotion of tumor cell metastasis and vasculogenic mimicry by way of transcription coactivation by Bcl-2 and Twist1: a study of hepatocellular carcinoma. Hepatology 2011;54:1690-1706.

48 Shen Y, Quan J, Wang M, Li S, Yang J, Lv M, Chen Z, Zhang L, Zhao X, Yang J: Tumor vasculogenic mimicry formation as an unfavorable prognostic indicator in patients with breast cancer. Oncotarget 2017; 8:56408-56416.

49 Cao Z, Bao M, Miele L, Sarkar FH, Wang Z, Zhou Q: Tumour vasculogenic mimicry is associated with poor prognosis of human cancer patients: a systemic review and meta-analysis. Eur J Cancer 2013;49:39143923. 